\title{
China Ceramic Tile Industrial Cluster Competitive Strategies under the Global Economy
}

\author{
Mei-hor Lo, Dechang Han \\ Business School, Nankai University, Tianjin, China \\ matthew@gearex.com.tw
}

\begin{abstract}
In the study, we discuss what changes come into play in the radical world markets, both for ceramic tiles and for surrounding ceramic tile supportive industries. These issues will be discussed with an amount of literature reviews through the various perspectives to explore the more comprehensive insight to China ceramic tile industry between globalization and local development. We analysis the theory of cluster and competitive theory to compare two ceramic tile clusters in the different context for tracing the mechanism and path constructed ceramic industry international competitiveness and strategy's formation.
\end{abstract}

Index Terms - Ceramic tile, industry cluster, agglomeration, competitive strategy, resource based view

\section{Introduction}

In common in most industries, ceramic tile industrys' innovative and upgrade capabilities regarded as a nation's major competitiveness Porter [1]. China's advantages in globalization and international tile industrial had been transferred and especially the advantages of the low-cost labor force are reducing. As the world's largest producer, consumer and exporter of ceramic tiles, the sheer scale of China's volumes has been driving world growth in production, consumption and exports for over 15 years [2]. Although China has apparent influence on the global tile volumes, however, Italy is a world leader in producing value added ceramic tiles, which manufactured by flexible and innovative small and medium enterprises (SMEs). Clusters have a prominent role to interconnect companies, specialized suppliers, service providers, firms in related industries, and associated institutions in a particular field that compete but also cooperate [3].

Chinese's ceramics developed variety of industrial products sourcing from living area urbanization, technology refinement, industrialization and mass-production that joined with cultural origin. Globalization is pushing Chinese's manufacturing companies have to face up to enormous qualitative and quantitative changes [4], ceramic tile industries as well. Globalization has increased the returns to productivity by opening up large new markets for China. Companies and employees have to face the new challenge by upgrading their productivity. How can Chinese ceramic tile firms succeed in the global marketplace? We have investigated the famous ceramic tile industry cluster-Foshan to discover competitive strategies under global economy and compared Sassuolo ceramic cluster by various angles.

Our research discussed two major concepts cluster and competitive capabilities, which have gained prestige in the economic and managerial fields since 1990s [5-7], however, mostly were not exploited in ceramic tile industry. Strong rivalry among ceramic tile firms grew more intense. We intend to refine the competitive strategies in China ceramic tile districts under globalized economy.

This study organized into five sections. Following section reviews cluster taxonomy and several theories related to competition. Section third illustrates Foshan industrial cluster. Section fourth will describe Italian ceramic industrial clusters and briefly exploit their localization and strategies of export. The final section contains the discussion and conclusions.

\section{Literature Review}

\section{A. Global Competitiveness of Resource-Base View}

According to Barney [5], firms will achieve a competitive advantage if their resources are valuable, rare, imperfectly imitable and non-substitutable. These assumptions have also implied that if firms can achieve sustainable competitiveness by strategies implemented [1, 5]. Prior perspective of organization boundaries in $\mathrm{RBV}$ focuses on the internal structure of firms rather than outside dynamic network. The new international economics has emphasized the role of geography as a key determinant for the economic performance of industries and as a way to enhance international competitiveness [8].

Hervás-Oliver and Albors-Garrigós [9] indicated that skilled labor availability, social capital, linkages, business sophistication and network effects composed a unique set of resources and capabilities to derive districts achieved better performance of the ceramic tile industry in Spain (Castellon) and Italy (Emilia-Romagna). Globalize trajectory makes capital flows speeding and hard to be predictive. The challenge for the policy maker is to build the industrial or state competitiveness to make firms gain sustainable, meanwhile, prosperity economy can be achieved. Porter, et al. [10] presented the foundation of competitiveness is determined by the productivity with which a nation's endowments are used to create goods and services. In the view of macroeconomic, endowments presented as the average of labor skills, capital, natural resources, country's geographic location and country size and population. van der Ploeg [11] brought another aspect in natural resource wealth has adverse effects are more severe in volatile countries with bad institutions and underdeveloped financial systems. The context of rules and incentives that govern firm strategy and rivalry is an important influence on how companies draw on the factor conditions that they face [12]. 
Resources and capabilities or higher-order capabilities of clusters are the result of the combination and interaction of all the localized elements self-reproduced and self-reinforced in the spatial context, including the strategies of located firms [6]. In addition to strategies of resource's administration, SMEs of ceramic sectors of EU demonstrated their competitive advantages of creative, innovative and high quality with greater flexibility to respond and adapt more quickly in the global market [13]. Moreover, these SMEs are not compete along Finally, when these resources and their related activity systems have complementarities, their potential to create sustained competitive advantage is enhanced [14]

\section{B. Industry Agglomeration and Cluster}

The most powerful empirical open innovation had been happened in Silicon Valley Route 128 that identified intellectual spillovers [15]. Marshall [16] regarded that plants will locate near other plants in the same industry within some characteristics shared and earned more benefits than separated one [17]. However, coagglomeration patterns means plants are similar to the other plants in their industry along many dimensions. But across industries, plants are similar in some dimensions and not in others. For example, some industry pairs exchange goods but employ very different workers. Other industries hire similar workers but never trade with each other [17, 18]. The basic concept of agglomeration economy synonymous means that production is facilitated when there is a clustering of economic activity.

Clusters formed in natural forces, which attribute to competitive advantages or geography reason; alternatively, in policies supports. In fact, many common surrounding services of the industrial clusters, such as consultancy and training to firms are the leading power for SMEs specialization, cooperation, and technological upgrade to the international market [19]. Russo [20] emphasized clusters play an increasing role in a global economy where the most competitive firms coagglomerated can serve wider markets unprotected across the geographical boundaries, especially among SMEs. Clusters provide a way of organizing thinking about many policy areas that goes beyond the common needs of the entire economy, listed as bellows [3].

- Advanced and specialized factor development

- Collection and dissemination of economic information

- Regulatory reform

- Export promotion

- Foreign direct investment promotion

- Focusing priorities and guide policies in science and technology, education and training.

In China, local industrial agglomerations are adopted as development tools and driving growth in wide areas. In a global economy, country's openness is forcing companies or industries to exploit competitive strategies and comparative advantages for market approaching, which formatted dynamic productivity. Clusters provide an intermediate unit of productivity drivers between the general business environment quality and firm level sophistication [12].

\section{Ceramic Tile Cluster of Foshan in China}

After four decades of undisputed leadership on the world market for tiles, Italy has now sunk to sixth place, behind China, Brazil, India, Iran and Spain. By 2012, China had produced 5,200 million square meters (sq.) which increased 8.3 percent, slower growth than during the previous two years, equivalent to 46.6 percent of world production. The growth in domestic consumption was just increased 6.3 percent, estimated at 4,250 million square meters, which occupied 38.9 percent of world consumption [2]. China's change was sourcing from economics openness and policy altered. Since 1980 s to 2000 s, many new firms entry into the ceramic tile industry in China, especially in Eastern China. The external element mainly attributed to the automatic manufacturing line and avant-garde machinery adopted for quality promoting which imported from ceramic district of Sassuolo. The efficiencies and quality had improved in 1990s [21]. Supported by strong inter-sectorial flows of knowledge in the field of machinery manufacturing and by a sharp increase of domestic demand, China is also beginning to produce machines for tile making, copying those developed in the Sassuolo district, which indirectly contributed producer-driven value chain [4].

In the meanwhile, internal factor might be attributed to two dimensions: organization's structure change and lower entry barriers. Chinas government liberated some state-own firms to be private-own; the organizational renovation of ceramic tile firms made the amount of skillful labor forces became the entrepreneurs. The entry barriers of this industryinitial capital and know-how acquire relatively almost insignificant. In this rapidly growing market, main manufacturers in China are concentrated in two major areas: Foshan and Eastern China. Foshan has a long history of ceramic fabrication, and is crowned the name of "Capital of Ceramic of China" which is the third-largest city in Guangdong. The ceramic reltions mainly centralized in Chancheng District where combine two towns of Nanzhuang and Shiwan since 2003. Nanzhuang is the greatest specialization in tile production of China, which manufactured enormous volume even greater than Italian national production [21]. With respect to Chinese's standards, the level of product quality is medium-high, most renowned brand are made in Foshan, such as New Pearl, New Zhong Yuan, Dongpeng. The trademark "Foshan ceramic" authorized by China's government in 2013. The population advantage, capabilities of technological absorb and nearby city development caused Foshan to become the major leading ceramic tile production districts in China as well as in the world market.

Ceramic tile cluster of Foshan was a typical type of Marshallian district, which creates a local pool of skilled workers, allowing the possibility of sharing investments in new and expensive machinery, and the creation of an 'industrial atmosphere' that enhances knowledge spillovers [22]. Foshan has taken the advantages of its low cost by mass production, low cost of labor, and rich raw materials with local made machinery, making Foshan manufactured over 30 percent tiles in domestic production and occupied over 70 
percent in domestic export. Local learning through ceramic communities of practice within the industrial district might be conducive to incremental innovation, along with a paradigm of Sassuolo. However, "imitating-modifying" is the common approach of learning leads homogeneous product and resulted excess supply with falling price. The need for low wages reveals a lack of competitiveness and devaluation results in a collective national pay while raising the cost of goods and services purchased abroad [23].

The SMEs in Foshan adopted OEM/ODM to export to global market, alternatively; the enterprise group or celebrated brand preferred domestic markets. Another feature varies from Italian pattern is the channel of distribution, building materials supermarkets or state exhibitions are the important channel for Chinese producers. Price's bargaining is normal for ceramic tiles transaction. Low switching costs for customer and dynamic real estate market derived unpredictable tile demanding. Asset's specialties of ceramic tile production made those SMEs to hold up overproduction in losing money risk. Overproduction also caused serious environment issues in those districts. Guangdong state government issued several policies about industries upgrading, raw materials governance and had moved 87 ceramic firms and dismantled 269 kilns and 155 powder silos [24].

Facing future challenges from all over the world, Foshan's core ceramic tile industry must consolidate all advantages of its strong demanding market and the low cost of production capability with market oriented branding strategy to continue taking the lead to the industry.

\section{Italian Ceramic Tile District of Sassuolo}

Based on formal interview to several managerial level of ceramic tile relations, the average cost of porcelain tile manufacturing are 10 dollars per square meter in Italy, 3.75 to 6 dollars in China in 2006. Italian tiles so far are the leading producer in physical characteristics, design, style, fashion, and image. Italy was the first country where tile production moved from craft to industry [20]. In terms of general tile products, the average import prices of US were 20.2 to 20.9 dollars by Italy and 8.3 to 8.7 dollars by China. Italian firms achieve the highest average price per square meter, based on the a fact that reflects the higher cost of Italian producers, in particular in terms of high quality inputs for high-end products. Italian firms dominate the France and German markets [2] but have a strong presence in the other high-end global market as well.

As well known, Italy has been the leader in the ceramic tile industry since the middle Ages. The industrial district of Sassuolo, situated in the hilly area between the provinces of Modena and Reggio in Emilia, where 80 percent of Italian tiles are manufactured and from where almost three-quarters of production is exported to world markets. The firms active today number 144, with more than 21 thousand employees and overall sales of more than 4 billion euro. Because of its performance, the process of industrialization in this area has been the subject of innumerable studies and research [20, 21, 25]. The main factors in the development of ceramic tile production in Sassuolo also following the natural advantage geographically: (a) easy access to raw materials (different kinds of clays) in the mountains in that area; (b) an abundant labor force unemployed in that area during the 1950s; (c) housing legislation changed of the early 1960s; (d) tax reliefs lasting till the middle of the 1970s [20].

Sassuolo ceramic tile districts have a unique context of economic, social and institutional features interact at a particular time within Italian historical developments of new techniques. The development of small-medium mechanical industries has benefited at the beginning from the consistent stream of skilled workers available, the greater part of which were trained right from the very beginnings inside the large firms. The presence of this competent workforce and the possibility has thus created conditions for technological development. Russo [20] deduced ceramic tile industry in Italy was shaped by the technology change, in terms of the process of invention, adoption and diffusion of new techniques in the industry which strengthen the interrelationships between firms and their proximity. In addition to product basis defined "industrial district", the process of technology change characterized organizational boundaries of firms.

Research developed largely outside the ceramic tile firms, such as the biggest Italian producer of presses for ceramic firms (SACMI). It lead the technical evolution of presses; the specialized technical and designing centers that have invented new firing techniques and developed the integrated system kiln-factory. Nowadays, some engineering firms still push forward R\&D development for specific ceramic tile factory as an integrated production line. Therefore, the pattern of vertical disintegration has been shaped by technical development through the collaboration of each proximity relation for the product and process specialization of the production units operating in the industrial district.

There are several international tile groups, such as Marazzi, Florim which have multiple distribution channels and set up flagship store in Milan for extraordinary Italian image. Most of all are SMEs, whereas 353 micro-firms fall below the $€ 2$ million threshold. Italian producers of ceramic tiles are deeply integrated in international trade, with 70 percent of total sales represented by exports to foreign markets [26]. Accordingly, the determinant of Sassuolo ceramic district is that the relations between the producers of machines for ceramic tile making and the producers of tiles, is also can imply to other ceramic production systems, such as Foshan ceramic tile industrial clusters in China, where is imitating technological changes of strategy on the part of the various actors in the Sassuolo district [4].

\section{Discussion and Conclusion}

Sassuolo ceramic industrial district has three benefits: first-mover advantage, tied-up proximity network of core industries within formal association and informal collaboration based on the trust and positive competitive environment. "Italian made" not only the quality reflected, but also contributed from first-mover with cultural reason. A strong network tie reduce the transaction costs that firms in industrial districts enable them to reap external economies of 
scale that can grant them lower costs than other competitors that are not geographically concentrated [8]. Three benefits get into a positive loop for achieving successful geographical concentration. We summarized the cluster paradigm of two clusters for comparison as below.

TABLE I Two clusters strategy's comparison

\begin{tabular}{|l|l|l|}
\hline & Foshan, China & Sassuolo, Italy \\
\hline Cluster paradigm & $\begin{array}{l}\text { Cost, economic scale, } \\
\text { customized OEM }\end{array}$ & $\begin{array}{l}\text { Style, design, image, tacit } \\
\text { knowledge }\end{array}$ \\
\hline $\begin{array}{l}\text { Main competitive } \\
\text { advantage }\end{array}$ & $\begin{array}{l}\text { Cheap price, } \\
\text { Brand image for domestic } \\
\text { market, } \\
\text { Competence of sales reps } \\
\text { Customer service; quick } \\
\text { delivery }\end{array}$ & $\begin{array}{l}\text { Design and technological } \\
\text { leadership } \\
\text { New applications for tiles } \\
\text { Mergers and acquisitions } \\
\text { Diversified brands image, } \\
\text { Competence of sales reps }\end{array}$ \\
\hline Distribution channel & $\begin{array}{l}\text { Building materials } \\
\text { supermarket } \\
\text { Independen distributor, } \\
\text { construction company }\end{array}$ & $\begin{array}{l}\text { Independent distributor, } \\
\text { home-center retailer, } \\
\text { construction company, } \\
\text { company-operated sales } \\
\text { center, specialised retail } \\
\text { shops }\end{array}$ \\
\hline $\begin{array}{l}\text { Internationalization } \\
\text { strategy }\end{array}$ & $\begin{array}{l}\text { Big firms major in } \\
\text { domestic market; global } \\
\text { export mostly by SMEs }\end{array}$ & $\begin{array}{l}\text { Global presence in all } \\
\text { potentially relevant markets } \\
\text { FDI in main markets }\end{array}$ \\
\hline
\end{tabular}

Source: Summarized from [21, 25]

We do concerns about what to do and how to do in the industrial clusters of China that can support firms gain competitiveness through integrated arguments by literature reviewing and several semi-structured interviews. Development trajectory of Industrial district of Foshan seems very similar with Sassuolo. Industrial cluster within sustainable competitiveness should be coexisting multiple sizes, various functions of firms and association with positive social interactions. There still is much to learn about clusters in the global economy with consolidated implications to rich the theories. Future research can offers more insight by different approaches to explore cluster's resources and capabilities from the view of worldwide that could frames clusters generally rather than practices in on special targets.

\section{References}

[1] M. E. Porter, "The Competitive Advantage of Nations," Harvard Business Review, vol. 68, pp. 73-93, Mar-Apr 1990.

[2] U. S. A. Luca Baraldi. (2013) World production and consumption of ceramic tiles. Ceramic world review. 42-60.

[3] M. E. Porter, "Location, Competition, and Economic Development: Local Clusters in a Global Economy," Economic Development Quarterly, vol. 14, pp. 15-34, 2000.

[4] M. Russo, "The ceramic industrial district facing the challenge from China," Dipartimento di Scienze Sociali, Cognitive e Quantitative. Università degli Studi di Modena e Reggio Emilia, 2004.

[5] J. Barney, "Firm Resources and Sustained Competitive Advantage," Journal of Management, vol. 17, pp. 99-120, Mar 1991.
[6] N. J. Foss, "Higher-order industrial capabilities and competitive advantage," Journal of Industry Studies, vol. 3, pp. 1-20, 1996.

[7] A. Markusen, "Sticky places in slippery space: a typology of industrial districts," Economic geography, pp. 293-313, 1996.

[8] F. McDonald and G. Vertova, "Geographical concentration and competitiveness in the European Union," European Business Review, vol. 13, pp. 157-165, 2001.

[9] J. L. Hervás-Oliver and J. Albors-Garrigós, "Do clusters capabilities matter? An empirical application of the resource-based view in clusters," Entrepreneurship and regional development, vol. 19, pp. 113-136, 2007.

[10] M. E. Porter, M. Delgado, C. Ketels, and S. Stern, "Moving to a New Glbal Competitiveness Index," in The Global Competitiveness Report 2008-2009, M. E. Porter and K. Schwab, Eds., ed Geneva, Switzerland: World Economic Forum, 2008, pp. 43-63.

[11] F. van der Ploeg, "Natural Resources: Curse or Blessing?," Journal of Economic Literature, vol. 49, pp. 366-420, 2011.

[12] K. Schwab and M. Porter, "The Global Competitiveness Report 2008$2009, " 2009$.

[13] C. Studies-ENTR, "FWC Sector Competitiveness StudiesCompetitiveness of the Ceramics Sector," ECORYS13 October 2008.

[14] J. L. Hervás-Oliver and J. Albors-Garrigós, "Do clusters capabilities matter? An empirical application of the resource-based view in clusters," Entrepreneurship \& Regional Development, vol. 19, pp. 113-136, 2007.

[15] A. Saxenian, Regional advantage: Culture and competition in Silicon Valley and Route 128: Harvard University Press, 1996.

[16] A. Marshall, Principles of economics vol. 1: Wirtschaft und Finanzen, 1890.

[17] G. Ellison, E. L. Glaeser, and W. R. Kerr, "What Causes Industry Agglomeration? Evidence from Coagglomeration Patterns," American Economic Review, vol. 100, pp. 1195-1213, 2010.

[18] G. Ellison and E. L. Glaeser, "The geographic concentration of industry: does natural advantage explain agglomeration?," The American Economic Review, vol. 89, pp. 311-316, 1999.

[19] F. Frattini and G. Prodi. (2013, Industrial clusters in China: Policy tools for further and more balanced development European Review of Industrial Economics and Policy (5). Available: http://revel.unice.fr/eriep/index.html?id=3476

[20] M. Russo, "Technical change and the industrial district: The role of interfirm relations in the growth and transformation of ceramic tile production in Italy," Research Policy, vol. 14, pp. 329-343, 1985.

[21] M.-H. Lo, "The Study of The Main Ceramic Tile Cluster in the World-Examples of Italy, Spain and Foshan China," M.B.A., College of Management, National Taiwan University, Taiwan, 2006.

[22] F. Belussi and S. R. Sedita, "Localized and distance learning in industrial districts," in Business networks in clusters and industrial districts: the governance of the global value chain, F. Belussi and A. Sammarra, Eds., ed New York: Routledge, 2010, p. 27.

[23] M. E. Porter, C. Ketels, and M. Delgado, "The Microeconomic Foundations of Prosperity: Findings from the Business Competitiveness Index," in The global competitiveness report 2007-2008, K. Schwab, M. E. Porter, and X. Sala-i-Martin, Eds., ed Geneva, Switzerland: Palgrave Macmillan Basingstoke, 2007, pp. 51-80.

[24] BBIC, "2010-2013 Chinese ceramic industry sector investment risk and credit strategy research report (Chinese version)," Beijing Business \& Intelligence Consulting Co. Ltd., Beijing2010.

[25] J. Meyer-Stamer, C. Maggi, and S. Siebel, "Upgrading in the tile industry of Italy, Spain and Brazil: insights from cluster and value chain analysis," Institute for Development and Peace, Gerhard-MercatorUniversity of Duisburg2001.

[26] E. Santarelli, "Entrepreneurship, Innovation, and The Evolution of Industrial Districts," in Entrepreneurship, Growth, and Innovation-The Dynamics of Firms and Industries, E. Santarelli, Ed., ed New York: Springer, 2006, p. 171. 